\title{
Oleamycins A and B: new antibacterial cyclic hexadepsipeptides isolated from a terrestrial Streptomyces sp.
}

\author{
Ritesh Raju ${ }^{1,2}$, Oleksandr Gromyko ${ }^{3}$, Butsiak Andriy ${ }^{3}$, Viktor Fedorenko ${ }^{3}$, Andriy Luzhetskyy ${ }^{1,2}$ \\ and Rolf Müller ${ }^{1,2}$
}

The Journal of Antibiotics (2014) 67, 339-343; doi:10.1038/ja.2014.1; published online 22 January 2014

Keywords: 19-membered cyclic hexadepsipeptide; glycine; natural products chemistry; piperazic acid

\section{DESCRIPTION}

Actinomycetes have been a source for anti-infectives for more than 50 years, and continue to have a very important role as the source organisms for the discovery of new antibiotics. In the course of our screening program for the discovery of new antibacterial compounds, one such strain (Lv20-58), recovered from the root zone of the plant Oleaceae europea came to our attention.

The strain (Lv20-58), later identified to belong to the genus Streptomyces was cultivated in M medium (61) for 8 days at $30^{\circ} \mathrm{C}$ and then extracted with ethyl acetate (61) to give a crude extract of $138.9 \mathrm{mg}$. The crude extract was partitioned between $20 \mathrm{ml}$ of hexane, $\mathrm{CH}_{2} \mathrm{Cl}_{2}$ and $\mathrm{MeOH}$ to afford $49.8,80.9$ and $10.6 \mathrm{mg}$ fractions, respectively. The $\mathrm{CH}_{2} \mathrm{Cl}_{2}$ fraction was subsequently purified by semipreparative reverse-phase HPLC to yield compounds $1\left(t_{\mathrm{R}}=30.5\right.$ $\min ; 2.5 \mathrm{mg}$ ) and $2\left(t_{\mathrm{R}}=28.6 \mathrm{~min}, 0.4 \mathrm{mg}\right)$. A detailed account of the spectroscopic analysis leading to the assignment of structures to oleamycin A (1) and oleamycin B (2) are presented below.

HR-ESI $(+)$ MS analysis of oleamycin A (1) (Table 1) revealed a pseudomolecular ion $\left([\mathrm{M}+\mathrm{Na}]^{+}\right)$indicative of a molecular formula $\left(\mathrm{C}_{39} \mathrm{H}_{66} \mathrm{~N}_{8} \mathrm{O}_{11} \mathrm{Na}\right)$ requiring 11 double bond equivalents. The NMR $\left(\mathrm{CDCl}_{3}\right)$ (Table 2) data revealed resonances for seven ester/amide carbonyls $\left(\delta_{\mathrm{C}} 169.2-177.1\right)$ requiring 1 to incorporate four rings. Early on in the structural elucidation phase we noticed the presence of two distinct set of resonances in the NMR (Table 2). As a result, we focused on the interpretation of the major set of resonances that led to the structural assignment of oleamycins. The 39 carbons and their assorted proton resonances were attributed to 2 primary methyls $\left(\delta_{\mathrm{C}}\right.$ 9.6 and 11.9), 3 secondary methyls $\left(\delta_{\mathrm{C}} 18.3,19.6\right.$ and 18.9), 3 tertiary methyls from which 2 were attributed to $N$-methyls $\left(\delta_{\mathrm{C}} 33.4\right.$ and 34.3), 14 methylenes $\left(\delta_{\mathrm{C}} 20.0-52.3\right), 7$ methines $\left(\delta_{\mathrm{C}} 29.9-82.1\right)$ and
9 quaternary carbons $\left.\left(\delta_{\mathrm{C}} 77.4-177.1\right)\right)$. Further analysis of the NMR data (Table 2, Figure 1) proposed that 1 was a new cyclic hexapeptide consisting of a 3-hydroxyleucine residue, three glycine residues (two of which were $N$-methylated) and two piperazic-acid residues. The sequence of the amino acids was determined by interpretation of key correlations observed in the HMBC spectra. Specifically, HMBC correlations from the methine $\mathrm{H}-3\left(\delta_{\mathrm{H}} 4.62\right)$ and methylene $\mathrm{H}_{2}-8$ $\left(\delta_{\mathrm{H}} 4.28,3.63\right)$ to the ester carbonyl C-7 $\left(\delta_{\mathrm{C}} 170.6\right)$. Additional correlations from $\mathrm{N}-\mathrm{Me}\left(\delta_{\mathrm{H}} 2.83\right)$ and the methylene $\mathrm{H}_{2}-10\left(\delta_{\mathrm{H}} 5.32\right.$, $3.36)$ to the amide carbonyl C-9 $\left(\delta_{\mathrm{C}} 169.3\right)$, extended by similar correlations from $\mathrm{N}-\mathrm{Me}\left(\delta_{\mathrm{H}} 3.07\right)$ and the methylene $\mathrm{H}_{2}-12\left(\delta_{\mathrm{H}} 4.54\right.$, $3.69)$ to the amide carbonyl $\mathrm{C}-11\left(\delta_{\mathrm{C}} 169.2\right)$ linked the $\mathrm{N}$-Me-glycine residues 2 and 3 . The amide $\mathrm{NH}\left(\delta_{\mathrm{H}} 7.53\right)$ of the third glycine residue and the methine $\mathrm{H}-14\left(\delta_{\mathrm{H}} 5.15\right)$ of the piperazic-acid residue (Pip1) showed correlations to C-13 $\left(\delta_{\mathrm{C}} 169.8\right)$, whereas $\mathrm{H}-14$ and $\mathrm{H}-19\left(\delta_{\mathrm{H}}\right.$ 5.50) showed correlations to C-18 (175.0). Finally, correlations from $\mathrm{H}-3$ and $\mathrm{H}-19$ to $\mathrm{C}-1$, led to the construction of the 19-membered cyclic hexapeptide fragment (Figure 1).

The second structural feature of $\mathbf{1}$ was identified to be a polyketide side chain (Figure 1). The ${ }^{1} \mathrm{H}$ NMR $\left(500 \mathrm{MHz}, \mathrm{CDCl}_{3}\right.$ ) (Table 2, Figure 1) and COSY data revealed a single isolated spin system, a primary methyl $\mathrm{H}_{3}-35\left(\delta_{\mathrm{H}} 0.84\right)$ with correlations to a methylene $\mathrm{H}_{2}$ $34\left(\delta_{\mathrm{H}} 1.09-1.24\right)$, methine $\mathrm{H}-33\left(\delta_{\mathrm{H}} 1.30-1.44\right)$, secondary methyl $\mathrm{H}_{3}-36\left(\delta_{\mathrm{H}} 0.98\right)$ and a methylene $\mathrm{H}_{2}-32\left(\delta_{\mathrm{H}} 0.98\right)$. A second primary methyl $\mathrm{H}_{3}-31\left(\delta_{\mathrm{H}} 0.79\right)$ extended to a methylene $\mathrm{H}_{2}-30\left(\delta_{\mathrm{H}} 1.25-\right.$ $1.37)$, a deshielded methine $\mathrm{H}-29\left(\delta_{\mathrm{H}} 3.53, \delta_{\mathrm{C}} 76.1\right)$ and finally to the methylenes $\mathrm{H}_{2}-27$ (1.30-1.38) and $\mathrm{H}_{2}-26$ (1.61-0.1.76). In the HMBC spectrum, a tertiary methyl $\mathrm{H}_{3}-37\left(\delta_{\mathrm{H}} 1.27\right)$ showed correlations to an amide carbonyl C-23 ( $\left.\delta_{\mathrm{C}} 177.1\right)$, oxycarbon C-24 $\left(\delta_{\mathrm{C}} 77.4\right)$ and hemiketal carbon $\mathrm{C}-25\left(\delta_{\mathrm{C}}\right.$ 99.1). The absence of a hydroxyl signal

${ }^{1}$ Department of Microbial Natural Products, Helmholtz Institute for Pharmaceutical Research Saarland, Helmholtz Centre for Infection Research (HZI), Saarland University, Saarbrücken, Germany; ${ }^{2}$ Department of Pharmaceutical Biotechnology, Saarland University, Saarbrücken, Germany and ${ }^{3}$ Department of Genetics and Biotechnology of Ivan Franko National University of L'viv, L'viv, Ukraine

Correspondence: Professor R Muller, Department of Microbial Natural Products, Helmholtz Institute for Pharmaceutical Research Saarland, Saarland University, Campus C2 3, Saarbrücken 66123, Germany.

E-mail: rom@mx.uni-saarland.de

Received 18 September 2013; revised 27 November 2013; accepted 24 December 2013; published online 22 January 2014 
Table 1 Physicochemical properties of 1 and 2

\begin{tabular}{lcc}
\hline & $\mathbf{1}$ & $\mathbf{2}$ \\
Appearance & Yellow solid & Yellow solid \\
\hline HR-ESI-MS $(\mathrm{m} / \mathrm{z})$ & & $831.4597[\mathrm{M}+\mathrm{Na}]^{+}$ \\
Found & $845.4742[\mathrm{M}+\mathrm{Na}]^{+}$ & $831.4592\left(\mathrm{C}_{38} \mathrm{H}_{64} \mathrm{~N}_{8} \mathrm{O}_{11} \mathrm{Na}\right)$ \\
Calcd & $845.4749\left(\mathrm{C}_{39} \mathrm{H}_{66} \mathrm{~N}_{8} \mathrm{O}_{11} \mathrm{Na}\right)$ & $(+) 15.6^{\circ}$ \\
{$[\alpha]_{\mathrm{D}}(\mathrm{MeOH})$} & $(+) 18.5$ & $210(4.67)$ \\
UV $\lambda_{\max } \mathrm{nm}(\log \varepsilon)(\mathrm{MeOH})$ & $210(4.67)$ & \\
\hline
\end{tabular}

Table 2 NMR ( $500 \mathrm{MHz}, \mathrm{CDCl} 3)$ data for 1

\begin{tabular}{|c|c|c|c|c|c|}
\hline Position & $\delta_{H}$, mult $(\mathrm{J}$ in $\mathrm{Hz})(\mathbf{1})$ & $\delta_{C}{ }^{a}$ & $\cos Y$ & $H M B C$ & ROESY \\
\hline \multicolumn{6}{|c|}{ 3-Hydroxyleucine } \\
\hline 1 & & 172.5 & & & \\
\hline 3 & $4.62^{\mathrm{b}}, \mathrm{dd}(6.7,2.9)$ & 82.1 & 2,4 & $1,2,4,5,6,7$ & $2 N-H, 4,5,6$ \\
\hline 4 & $1.89, \mathrm{~m}$ & 29.9 & $3,5,6$ & 5,6 & 3 \\
\hline 5 & $1.02, \mathrm{~d}(6.9)$ & 19.6 & 4 & $3,4,6$ & 2,3 \\
\hline \multicolumn{6}{|c|}{ Glycine (1) } \\
\hline 7 & & 170.6 & & & \\
\hline $8 a$ & $4.28, d(17.0)$ & 52.3 & $8 b$ & $7,9,38$ & \\
\hline $8 b$ & $3.63, d(17.0)$ & & $8 a$ & $7,9,38$ & 38 \\
\hline \multicolumn{6}{|c|}{ Glycine (2) } \\
\hline 9 & & 169.3 & & & \\
\hline $12 a$ & $4.54, \mathrm{dd}(16.6,9.7)$ & 40.8 & $12 \mathrm{~b}, 12 \mathrm{~N}-\mathrm{H}$ & 11 & \\
\hline $12 \mathrm{~b}$ & 3.69 & & $12 \mathrm{a}, 12 \mathrm{~N}-\mathrm{H}$ & & $12 N-H, 39$ \\
\hline $12 N-\mathrm{H}$ & 7.53, d (9.7) & & $12 \mathrm{a} / \mathrm{b}$ & 13 & $12 b, 14$ \\
\hline \multicolumn{6}{|c|}{ Piperazic acid (1) } \\
\hline 13 & & 169.8 & & & \\
\hline 14 & $5.15, \mathrm{~m}$ & 52.8 & $15 \mathrm{a} / \mathrm{b}$ & $13,15,16,18$ & $12 \mathrm{~N}-\mathrm{H}, 15 \mathrm{a} / \mathrm{b}$ \\
\hline $15 a$ & $2.51, \mathrm{~m}$ & 23.6 & $14,15 b, 16$ & & 14 \\
\hline $15 b$ & $1.64, \mathrm{~m}$ & & $14,15 a, 16$ & & 14 \\
\hline 16 & $1.56, \mathrm{~m}$ & 22 & $15 \mathrm{a} / \mathrm{b}, 17 \mathrm{a} / \mathrm{b}$ & $12,15,16$ & \\
\hline $17 a$ & $3.14^{c}, \mathrm{~m}$ & 48.1 & $16,17 \mathrm{~N}-\mathrm{H}, 17 \mathrm{~b}$ & $13,14,16$ & \\
\hline $17 b$ & $2.73, \mathrm{~m}$ & & $16,17 \mathrm{~N}-\mathrm{H}, 17 \mathrm{a}$ & & \\
\hline $22 b$ & $2.93, \mathrm{~m}$ & & $21 \mathrm{a} / \mathrm{b}, 22 \mathrm{~b}, 22 \mathrm{~N}-\mathrm{H}$ & & \\
\hline $22 N-H$ & $4.62^{b}$ & & $22 \mathrm{a} / \mathrm{b}$ & & \\
\hline \multicolumn{6}{|l|}{ Polyketide } \\
\hline 23 & & 177.1 & & & \\
\hline 24 & & 77.4 & & & \\
\hline 25 & & 99.1 & & & \\
\hline 26 & $1.61-1.76, \mathrm{~m}$ & 27.9 & 27 & 25 & \\
\hline 27 & $1.30-1.38$ & 24.1 & 26,28 & & \\
\hline 28 & $1.17-1.29, \mathrm{~m}$ & 36.8 & 27,29 & & \\
\hline 29 & $3.53, \mathrm{dt}(10.1,2.5)$ & 76.1 & 28,30 & 31 & \\
\hline
\end{tabular}


Table 2 (Continued)

\begin{tabular}{|c|c|c|c|c|c|}
\hline 30 & $1.25-1.37, \mathrm{~m}$ & 25.5 & 29,31 & & \\
\hline 31 & 0.79 & 9.6 & 30 & 29,30 & \\
\hline 33 & $1.30-1.44, \mathrm{~m}$ & 31.3 & $32,34,36$ & & \\
\hline 34 & $1.09-1.24$ & 31.4 & 33,35 & & \\
\hline 35 & 0.84 & 11.9 & 34 & 33,34 & \\
\hline 38 & $2.83, \mathrm{~s}$ & 34.3 & & 8,9 & $8 b$ \\
\hline 39 & $3.07, \mathrm{~s}$ & 33.4 & & 10,11 & $12 b$ \\
\hline
\end{tabular}

aAssignments supported by HSQC and HMBC.

boverlapping signals.

cOverlapping signals.

dOverlapping signals.

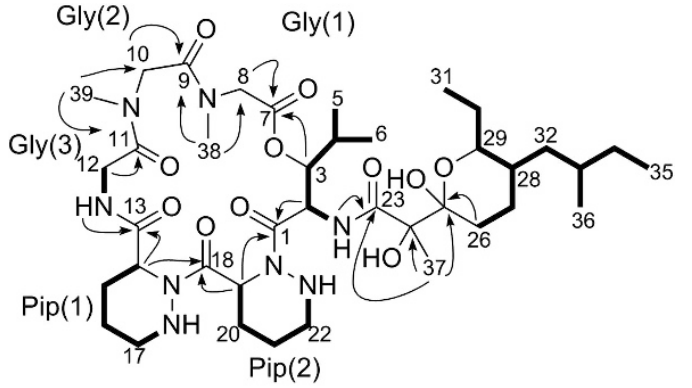

- $\cos Y$

$\longrightarrow$ HMBC

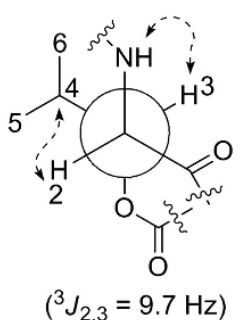

Figure 1 Key 2D NMR ( $500 \mathrm{MHz}, \mathrm{CDCl}_{3}$ ) correlations for 1 and Newman projection showing relative configuration of $\mathrm{C} 2 / \mathrm{C} 3$.

associated with C-29 suggested that it has an ether linkage, which was attributed to the likely presence of a heterocyclic system. This was supported by $\mathrm{HMBC}$ correlations from the methylene $\mathrm{H}_{2}-26\left(\delta_{\mathrm{H}}\right.$ 1.61-1.76) to C-25, suggesting the presence of a tetrahydropyran ring. A large coupling $\left(J_{29,28}=10.1 \mathrm{~Hz}\right)$ established a trans-diequatorial relationship orientation of the substituents at C-28 and C-29. The point of attachment of the polyketide unit to the peptide was established on the basis of HMBC correlations of the amide $2 \mathrm{~N}-\mathrm{H}$ ( $\delta_{\mathrm{H}}$ 8.00) and the tertiary methyl $\mathrm{H}_{3}-37\left(\delta_{\mathrm{H}} 1.27\right)$ to the amide carbonyl C-23 $\left(\delta_{\mathrm{C}} 177.1\right)$, leading to the overall planar structure of $\mathbf{1}$ (Figure 2). The relative configuration of the two stereogenic centers in $\beta$-OH-Leu was established as $2 S^{*}$ and $3 S^{*}$ by ROESY and $J$-based configuration analysis ${ }^{1}$ (Figure 1). Despite the absence of a ROESY correlation from the methine $\mathrm{H}-4$ to $2 \mathrm{~N}-\mathrm{H}$, we have drawn the $\mathrm{C} 2-\mathrm{C} 3$ rotamer as follows, based on the absolute configuration identified as $(2 S, 3 S)$ of the $\beta$-OH-Leu residue in the known 19-membered cyclic depsipeptides (A83586C, L-156,602, aurantimycins, polyoxypeptins, GE3 and dentigerumycin; Figure 2). HRESI $(+)$ MS analysis of oleamycin B (2) (Supplementary Table S1) revealed a pseudomolecular ion $\left([\mathrm{M}+\mathrm{Na}]^{+}\right)$indicative of a molecular formula $\left(\mathrm{C}_{38} \mathrm{H}_{64} \mathrm{~N}_{8} \mathrm{O}_{11} \mathrm{Na}\right)$ requiring 11 double bond equivalents (Table 1 ). The principle difference of $\mathbf{2}$ over $\mathbf{1}$ was the substituent on the tetrahydropyran ring from an isobutyl to an isopropyl residue (C32-C-35) (Figure 2). The closest known natural product analogs to $\mathbf{1}$ and $\mathbf{2}$ are the rare class of 19 -memebered cyclic hexadepsipeptides azinothricin, ${ }^{2}$ A83586C,${ }^{3}$ L-156,602, ${ }^{4}$ citropeptin, ${ }^{5}$ variapeptin, ${ }^{6}$ verucopeptin, ${ }^{7}$ aurantimycins, ${ }^{8}$ polyoxypeptins, ${ }^{9}$ piplamycin, ${ }^{10}$ IC101, ${ }^{11} \mathrm{GE}^{12}$ (Figure 2) and the recently reported dentigerumycin. ${ }^{13}$ Oleamycin A (1) displayed significant biological activity against a panel of Gram-positive bacteria and a cancer cell line (HCT-116). It is noteworthy that MIC's were against strains $S$. aureus $\left(0.23 \mu \mathrm{g} \mathrm{ml}^{-1}\right)$ and Micrococcus luteus $\left(0.03 \mu \mathrm{g} \mathrm{ml}^{-1}\right)$, whereas an $\mathrm{IC}_{50}$ of $6.5 \mathrm{ng} \mathrm{ml}^{-1}$ was recorded against HCT-116 cells (human colon carcinoma). Owing to the limited supply of oleamycin B (2) and reproducibility issues in the fermentation, we were unable to screen for its biological activity. In summary, we have isolated, characterized and evaluated the biological activity of two new members, oleamycin A (1) and B (2), of the well-described 19-membered cyclic depsipeptides.

\section{EXPERIMENTAL PROCEDURE}

NMR spectra were obtained on a Bruker Ascend $500 \mathrm{MHz}$ spectrometer equipped with a cryoprobe system (Bruker Biospin GmbH, Rheinstetten, Germany) in the solvents indicated and referenced to residual ${ }^{1} \mathrm{H}$ signals in deuterated solvents. ESI-MS were acquired using an Agilent 1100 Series separations module equipped with an Agilent 1100 Series LC/MSD mass detector (Agilent, Waldbronn, Germany) in both positive and negative ion modes under the following conditions: Zorbax $\mathrm{C}_{8}$ column (Crawford Scientific, Lanarkshire, UK), $150 \times 4.6 \mathrm{~mm}^{2}$, eluting with $0.4 \mathrm{ml} \mathrm{min}^{-1} 95 \%$ $\mathrm{H}_{2} \mathrm{O} / \mathrm{MeCN}$ to $5 \% \mathrm{H}_{2} \mathrm{O} / \mathrm{MeCN}$ (with isocratic $0.01 \%$ trifluoroacetic acid) over $22 \mathrm{~min}$, and then held for $5 \mathrm{~min}$. HR-MS was carried out using an UltiMate 3000 rapid separation LC system (Dionex RSLC, Idstein, Germany) coupled to an ultra-high resolution time-of-flight MS (Bruker Daltonik MaXis, Bremen, Germany) operating in the positive ESI mode.

Sampling was performed in the Nikitsky Botanical Garden of Crimea (Ukraine). The soil (1 g) was collected from the root zone of O. europea and resuspended in sterile water, followed by serial dilutions leading to the inoculation onto the oatmeal agar (oatmeal $40 \mathrm{gl}^{-1}$, agar $15 \mathrm{gl}^{-1}, \mathrm{pH} 7.5$ ). The plates were incubated for 20 days at $28^{\circ} \mathrm{C}$. Individual colonies were transferred onto new oatmeal agar plates for further analysis and cryopreservation. The 16S ribosomal DNA sequence analysis of strain Lv20-58 classified it 

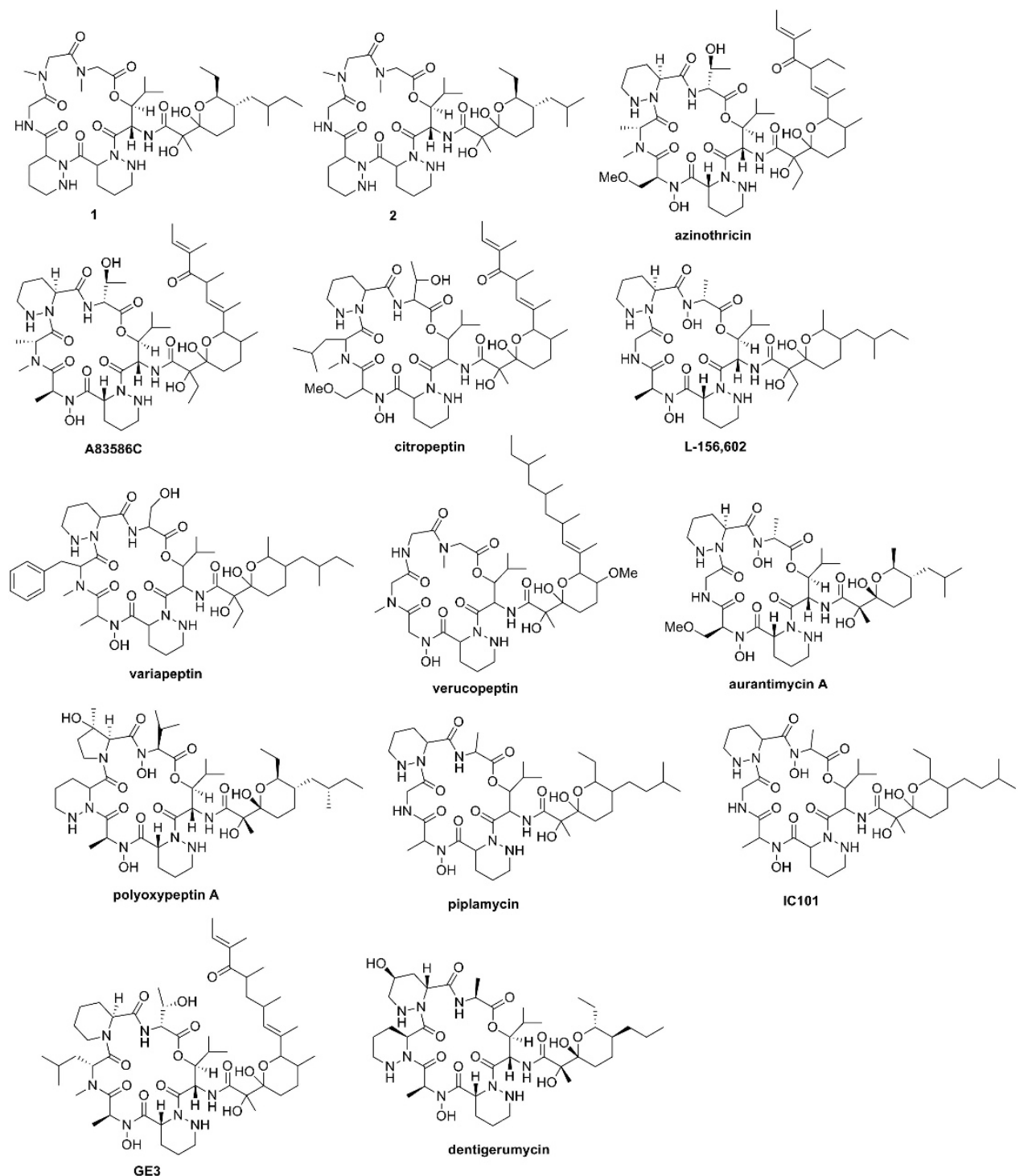

IC101

Figure 2 Structures of 1,2 and related metabolites.

to belong to the genus Streptomyces. The strain Streptomyces sp., Lv20-58, is deposited in the microorganism collection of Ivan Franko Lviv National University.

Strain Lv 20-58 was cultivated in a $(250 \mathrm{ml})$ Schott flask containing M1 (1\% starch, $0.4 \%$ yeast extract and $0.2 \%$ peptone) prepared in distilled water $(80 \mathrm{ml})$. The strains were shaken at 150 r.p.m. for 8 days at $30^{\circ} \mathrm{C}$, extracted with EtOAc $(50 \mathrm{ml})$ and the organic phase was concentrated in vacuo to yield a crude extract of $3.4 \mathrm{mg}$. The crude extracts were redissolved in $\mathrm{MeOH}$ generating a concentration of $1 \mathrm{mg} \mathrm{ml}^{-1}$ and analyzed using HPLC-DAD$\operatorname{ESI}( \pm) \mathrm{MS}$.

Five 51 Erlenmeyer flasks containing M1 broth (1.21) were inoculated with starter culture $(20 \mathrm{ml})$ of Streptomyces sp. The flasks were incubated at $30^{\circ} \mathrm{C}$ on a rotary shaker at 150 r.p.m. for $8 \mathrm{~d}$, extracted with EtOAc $\left(2 \times 500 \mathrm{ml}^{2}\right.$ per flask) and the organic phases were concentrated in vacuo to yield a combined EtOAc extract $(167.6 \mathrm{mg})$. The EtOAc extract was sequentially triturated with hexane, $\mathrm{CH}_{2} \mathrm{Cl}_{2}$ and $\mathrm{MeOH}$ ( $40 \mathrm{ml}$ aliquots), which were concentrated in vacuo, to yield $37.8,77.9$ and $30.6 \mathrm{mg}$ partitions, respectively. The $\mathrm{CH}_{2} \mathrm{Cl}_{2}$ soluble material was further fractionated by HPLC (Zorbax, $\mathrm{C}_{8}$ column, $250 \times 9.4 \mathrm{~mm}^{2}, 5 \mu \mathrm{m}, 3 \mathrm{ml} \mathrm{min}^{-1}$, gradient from 10 to $100 \%$ acetonitrile- $\mathrm{H}_{2} \mathrm{O}$ over $30 \mathrm{~min}$, with a $100 \%$ acetonitrile hold for $5 \mathrm{~min}$ ) to afford oleamycin A (1) $\left(t_{\mathrm{R}}=30.5 \mathrm{~min}, 1.6 \mathrm{mg}\right)$ and oleamycin B (2) $\left(t_{\mathrm{R}}=28.6 \mathrm{~min}, 0.4 \mathrm{mg}\right)$.

\section{ACKNOWLEDGEMENTS}

We thank Viktoria Schmitt for performing the biological assays. Research in R.M.'s laboratory was supported by grants from the BMBF and the DFG.

1 Matsumori, N., Kaneno, D., Murata, M., Nakamura, H. \& Tachibana, K. Stereochemical determination of acyclic structures based on carbon-proton spin-coupling constants. A method of configuration analysis for natural products. J. Org. Chem. 64, 866-876 (1999).

2 Maehr, H. et al. Microbial products. 8. Azinothricin, a novel hexadepsipeptide antibiotic. J. Antibiot. 39, 17-25 (1986).

3 Smitka, T. A. et al. A83586C, a new depsipeptide antibiotic. J. Antibiot. 41, 726-733 (1988)

4 Hensens, O. D. et al. L-156,602, a C5a anatagonist with a novel cyclic hexadepsipeptide structure from Streptomyces sp. MA6348. Fermentation, isolation and structure determination. J. Antibiot. 44, 249-254 (1991).

5 Hayakawa, Y., Nakagawa, M., Toda, Y. \& Seto, H. A new depsipetide antibiotic, citropeptin. Agric. Biol. Chem. 54, 1007-1011 (1990).

6 Nakagawa, M., Hayakawa, Y., Adachi, K. \& Seto, H. A new depsipeptide antibiotic, variapeptin. Agric. Biol. Chem. 54, 791-794 (1990).

7 Sugawara, K., Toda, S., Moriyama, T., Konishi, M. \& Oki, T. Verucopeptin, a new antitumor antibiotic active against B16 melanoma. 2. Structure determination. J. Antibiot. 46, 928-935 (1993). 
8 Grafe, U. et al. Aurantimycins, new depsipeptide antibiotics from Streptomyces auranticus IMET-43917 production, isolation, structure elucidation, and biological activity. J. Antibiot. 48, 119-125 (1995).

9 Umezawa, K., Nakazawa, K., Ikeda, Y., Naganawa, H. \& Kondo, S. Polyoxypeptins A and B produced by Streptomyces: apoptosis-inducing cyclic depsipeptides containing the novel amino acid (2S,3R)-3-hydroxy-3-methylproline. J. Org. Chem. 64, 3034-3038 (1999).

10 Uchihata, Y. et al. Isolation of a novel cyclic hexadepsipeptide piplamycin from Streptomyces as an apoptosis-inducing agent. J. Antibiot. 55, 1-5 (2002).
11 Ueno, M. et al. IC101, extracellular-matrix antagonist produced by Streptomyces sp. MJ202-72F3-Production, isolation, structure determination and biological activity. J. Antibiot. 46, 1658-1665 (1993).

12 Agatsuma, T., Sakai, Y., Mizukami, T. \& Saitoh, Y. GE3, a novel hexadepsipeptide antitumor antibiotic produced by Streptomyces sp. 2. Structure determination. J. Antibiot. 50, 704-708 (1997).

13 Oh, D.-C., Poulsen, M., Currie, C. R. \& Clardy, J. Dentigerumycin: a bacterial mediator of an ant-fungus symbiosis. Nat. Chem. Biol. 5, 391-393 (2009).

Supplementary Information accompanies the paper on The Journal of Antibiotics website (http://www.nature.com/ja) 